\title{
HUBUNGAN ANTARA PENGGUNAAN LABORATORIUM IPA DAN KOMPTENSI GURU DENGAN HASIL BELAJAR BIOLOGI SISWA SMAN I CIBUNGBULANG KABUPATEN BOGOR
}

\author{
Nawawi ${ }^{1}$, Turdjai ${ }^{2}$, Zainal Abidin Arief $^{3}$ \\ Program Studi Teknologi Pendidikan Pascasarjana UIKA Bogor \\ Jl. KH. Sholeh Iskandar Km. 2 Kd. Badak, Bogor \\ (nawawi1964@yahoo.co.id)
}

\begin{abstract}
Abstrak: Tujuan penelitian ini adalah Untuk mengetahui pengaruh penggunaan laboratorium dan kompetensi guru terhadap peningkatan hasil belajar siswa pada bidang studi IPA di SMAN Cibungbulang. Metode penelitian yang digunakan adalah metode penelitian kuantitatif dengan pendekatan korelasional. Dari hasil analisis data disimpulkan sebagai berikut: (1) Terdapat hubungan antara variabel penggunaan Laboratorium IPA dengan hasil belajar siswa dengan nilai probabilitas sig. $0.003<0,05$, (2) Terdapat hubungan antara variabel kompetensi guru terhadap hasil belajar siswa, dengan nilai probabilitas sig. $0.027<0,05$, (3) Terdapat hubungan yang signifikan antara variabel penggunaan Laboratorium IPA dan kompetensi guru dengan hasil belajar siswa, dengan nilai probabilitas sig. $0.010<0,05$. Dengan demikian hipotesis alternatif yang menyatakan terdapat hubungan simultan yang signifikan antara variabel penggunaan Laboratorium IPA dan kompetensi guru dengan hasil belajar siswa dapat diterima. Variabel pemanfaatan Laboratorium IPA dan kompetensi guru memberikan kontribusi sebesar 19,8\% terhadap hasil belajar siswa, sedangkan sisanya $(100-19,8)=80,19 \%$ hasil belajar dipengaruhi oleh faktor lainnya di luar variabel yang diteliti.
\end{abstract}

Kata Kunci: Laboratorium, Kompetens Guru, Hasil Belajar

Abstract : The purpose of this study was to determine the effect of the use of laboratory and competence of teachers can improve student learning outcomes in the field of science studies at SMAN 1 Cibungbulang. The method used is quantitative research methods with the correlational approach. From the analysis of the data summarized as follows : (1) There is a relationship between variables of laboratory science student learning outcomes with a probability value sig $.0 .003<0.05$, (2) There is a relationship between the variables of teacher competence on student learning outcomes, with a probability value of sig $.0 .027<0.05$, (3) There is a significant relationship between the variables and the use of laboratory science teacher competence in student learning outcomes, with a probability value of sig. $0.010<0.05$. Thus the alternative hypothesis that states there is a significant relationship between the variables simultaneous use of laboratory science and competence of teachers with student learning outcomes are acceptable. Variable utilization of laboratory science and teacher competence accounted for $19.8 \%$ of the student learning outcomes, while the rest $(100 \%-19,8 \%)=80.19 \%$ learning outcomes are influenced by other factors outside of the variables studied.

Keyword: Laboratory, Master of competence, Learning Outcomes

\section{PENDAHULUAN}

\subsection{Latar Belakang}

Hampir di semua sekolah menengah, mata pelajaran IPA/Biologi menempati posisi yang unik. Pelajaran IPA/Biologi mempunyai posisi yang penting, diterapkan di hampir semua disiplin ilmu yang lain. IPA/Biologi juga menjadi salah satu mata pelajaran yang diujikan sebagai Ujian Akhir Nasional, dengan demikain menjadi salah satu mata pelajaran yang memberi kontribusi pada keberhasilan atau kegagalan siswa.

Disisi yang lain, sifat mata pelajaran IPA/Biologi yang bersifat abstrak dan hierarkis menyebabkan tingkat kesulitan yang relatif tinggi pada siswa yang mempelajarinya. 
Kesulitan ini tampak pada indikator pencapaian hasil belajar yang relatif lebih rendah dibandingkan dengan mata pelajaran yang lain. Sementara itu, pengukuran pencapaian hasil belajar lebih menekankan pada aspek kognitif saja.

Misalkan pada pengujian akhir, baik tingkat daerah atau nasional. Dua aspek yang lain yaitu: afektif dan psikomotorik, sering diabaikan dan tidak mendapat tempat dalam pembelajaran. Hal ini terutama disebabkan karena pembelajaran lebih ditujukan pada tuntutan kognitif, yang secara formal diukur dalam bentuk ujian akhir. Kondisi tersebut diatas, menyebabkan pembelajaran di kelas menjadi terasa kering, membosankan, menakutkan dan bahkan mengkerdilkan motivasi siswa dalam belajar. Tidak jarang, para siswa merasa tidak nyaman, tidak aman bahkan mengalami tekanan luar biasa dalam mengikuti pembelajaran di kelas.

Salah satu upaya untuk mengurangi atau mendekatkan konsep-konsep dalam pelajaran IPA/Biologi dilakukan dengan 'membumikan' konsep-konsep tersebut dalam penerapan pada aspek aspek kehidupan yang terkait dengan kehidupan siswa.

Pengajaran sebagai suatu proses merupakan suatu sistem yang melibatkan berbagai bagian antara lain pendidik (guru), peserta didik (siswa), materi, sumber belajar, media pembelajaran, metode dan lain sebagainya. Berbagai bagian tersebut saling berinteraksi satu dengan yang lainnya. Keberhasilan pengajaran sangat ditentukan manakala pengajaran tersebut mampu mengubah diri peserta didik. Perubahan tersebut dalam arti dapat menumbuh kembangkan potensi-potensi yang dimiliki peserta didik sehingga peserta didik dapat memperoleh manfaatnya secara langsung dalam perkembangan pribadinya. Tanggung jawab keberhasilan pengajaran tersebut berada di tangan seorang pendidik. Artinya, seorang guru harus berupaya semaksimal mungkin untuk mengatur proses pembelajaran sedemikian rupa sehingga komponenkomponen yang diperlukan dalam pengajaran tersebut dapat berinteraksi satu sama lain.
Pembelajaran IPA sebaiknya dilaksanakan secara inkuiri ilmiah (scientific inquiry) untuk menumbuhkan kemampuan berpikir, bekerja dan bersikap ilmiah serta mengkomunikasikannya sebagai aspek penting kecakapan hidup. Oleh karena itu pembelajaran IPA di SMP/MTs menekankan pada pemberian pengalaman belajar secara langsung melalui penggunaan dan pengembangan keterampilan proses dan sikap ilmiah. Standar Kompetensi (SK) dan Kompetensi Dasar (KD) IPA di SMP/MTs merupakan standar minimum yang secara nasional harus dicapai oleh peserta didik dan menjadi acuan dalam pengembangan kurikulum di setiap satuan pendidikan. Pencapaian SK dan KD didasarkan pada pemberdayaan peserta didik untuk membangun kemampuan, bekerja ilmiah, dan pengetahuan sendiri yang difasilitasi oleh guru.

Mata pelajaran IPA di yang di berikan di SMA banyak melakukan percobaan. Dengan melakukan eksperimen langsung di laboratorium siswa dapat mengamati secara langsung perubahan-perubahan yang terjadi, yang pada akhirnya dapat menemukan sendiri konsep yang akan dipelajarinya, sehingga pembelajaran yang terjadi lebih bermakna bagi siswa.

Guru merupakan komponen pendidikan terpenting, terutama dalam mengatasi berbagai permasalahan yang berkaitan dengan peningkatan mutu pendidikan. Dalam kaitan ini, yang dapat memperbaiki situasi pendidikan pada akhirnya berpulang kepada guru yang sehari-hari bekerja di lapangan. Dengan demikian, untuk memperbaiki mutu pendidikan di Indonesia, perlu dikaji eksistensi guru sebagai current issue. Guru merupakan orang-orang yang bertanggung jawab terhadap perkembangan peserta didiknya dengan upaya mengembangkan seluruh potensi peserta didik, baik potensi afektif (rasa), kognitif (cipta), maupun psikomotorik (karsa).

Menurut Balitbang Depdiknas, lebih dari 30 persen guru yang ada sekarang ini sebenarnya tidak layak untuk mengajar. Mereka sebenarnya tidak terpanggil untuk 
menjadi pendidik, namun hanya karena keterpaksaan. Dengan keadaan demikian, akan melahirkan komitmen yang rendah dari guru terhadap sekolahnya.

Berdasarkan pada paparan latar belakang di atas, penulis tertarik untuk mengkaji hal tersebut dalam sebuah tesis dengan judul: "Hubungan antara Penggunaan Laboratorium IPA dan Kompetensi Guru dengan Hasil Belajar Biologi Siswa SMAN 1 Cibungbulang Kabupaten Bogor".

\subsection{Rumusan Masalah}

Berdasarkan latar belakang dan pembatasan masalah yang penulis paparkan di atas, maka secara rinci rumusan masalah penelitian pada tesis ini dirumuskan sebagai berikut:

1. Apakah terdapat hubungan antara penggunaan laboratorium dengan hasil belajar siswa pada bidang studi IPA di SMAN Cibungbulang?

2. Apakah terdapat hubungan antara kompetensi guru dengan hasil belajar siswa pada bidang studi IPA di SMAN Cibungbulang?

3. Apakah terdapat hubungan antara penggunaan laboratorium dan kompetensi guru secara simultan dengan hasil belajar siswa pada bidang studi IPA di SMAN Cibungbulang?

\subsection{Tujuan Penelitian}

Tujuan yang ingin dicapai dari kegiatan penelitian ini antara lain:

1. Untuk mengetahui hubungan antara penggunaan laboratorium dengan hasil belajar siswa pada bidang studi IPA di SMAN Cibungbulang.

2. Untuk mengetahui hubungan antara kompetensi guru dengan hasil belajar siswa pada bidang studi IPA di SMAN Cibungbulang.

3. Untuk mengetahui hubungan antara penggunaan laboratorium dan kompetensi guru secara simultan dengan hasil belajar siswa pada bidang studi IPA di SMAN Cibungbulang.

\section{TINJAUAN TEORI}

\subsection{Kerangka Teoritik}

\subsubsection{Hasil Belajar \\ Pengertian Hasil Belajar}

Hasil belajar dalam penelitian ini merupakan kemampuan yang dimiliki siswa setelah melakukan kegiatan belajar berupa skor hasil tes dalam aspek kemampuan kognitif untuk bidang studi IPA pada pokok bahasan "Memahami polusi dan dampaknya pada manusia dan lingkungan" dalam bentuk pilihan ganda untuk ranah ingatan (C1) dan pemahaman $(\mathrm{C} 2)$.

Beberapa pendapat para ahli tentang pengertian hasil belajar, antara lain menurut Agus Suprijono, yang menyatakan bahwa: Hasil belajar adalah pola-pola perbuatan, nilainilai, pengertian-pengertian, sikap-sikap, apresiasi dan keterampilan berupa: Informasi verbal yaitu kapabilitas mengungkapkan pengetahuan dalam bentuk bahasa, baik lisan maupun tertulis. Kemampuan merespons secara spesifik terhadap rangsangan spesifik. Kemampuan tersebut tidak memerlukan manipulasi simbol, pemecahan masalah maupun penerapan aturan.

Proses pembelajaran tidak berhenti atau belum dianggap berhasil bila terdapat perubahan hanya pada pengetahuan (kognitif) saja, tetapi juga harus diiringi dengan perubahan dari segi psikomotor dan efektif, karena seseorang yang tingkat kognitifnya (pengetahuannya) bagus belum tentu ia bisa melakukan atau memperaktekkannya dan bersikap sesuai dengan apa yang ia ketahui sebagai hasil dari aktifitas dalam belajar

\section{Jenis-Jenis Belajar \\ Jenis-jenis belajar yang diuraikan dalam pembahasan berikut ini merupakan penggabungan dari pendapat ketiga ahli. Walaupun begitu, dari pendapat ketiga para ahli, ada jenis-jenis belajar tertentu yang tidak dibahas dalam kesempatan ini, dengan pertimbangan sifat buku yang dibahas.}

Menurut Slameto (2010:5-8) terdapat bermacam-macam jenis belajar yang dapat dilakukan seseorang yaitu: 
1) Belajar bagian (part learning, fractioned learning)

Belajar bagian dilakukan oleh seseorang bila dihadapkan pada materi belajar yang bersifat luas dan ekstensif, misalnya, mempelajari sajak ataupun mempelajari gerak-gerakan seperti bermain silat.

2) Belajar dengan wawasan (learning by insight)

Wawasan merupakan pokok utama dalam pembicaraan psikologi belajar dan proses berpikir. Belajar wawasan merupakan proses mereorganisasikan pola-pola tingkah laku yang telah terbentuk menjadi satu tingkah laku yang ada hubunganya dengan penyelesaian atau persoalan.

\section{Prinsip-Prinsip Belajar}

Prinsip-prinsip Belajar Menurut Agus Suprijono (2009:4-5) yaitu:

1) Prinsip belajar adalah perubahan perilaku. Perubahan perilaku sebagai hasil belajar memiliki berbagai ciri.

2) Belajar merupakan proses. Belajar terjadi karena didorong kebutuhan dan tujuan yang ingin dicapai. Belajar adalah proses sistemik yang dinamis, konstruktif, dan organik. Belajar merupakan kesatuan fungsional dari berbagai komponen belajar.

3) Belajar merupakan bentuk pengalaman. Pengalaman pada dasarnya adalah hasil dari interaksi antara peserta didik dengan lingkungannya. William Burton mengemukakan bahwa $A$ good learning situation consist of a rich and varied series of learning experiences unified around a vigorous purpose and carried on in interaction with a richt varied and propocative environment.

\subsubsection{Laboratorium IPA}

\section{Pengertian Laboratorium IPA}

Laboratorium dapat diartikan secara luas maupun sempit. Dalam Kamus Bahasa Indonesia, laboratorium adalah tempat mengadakan percobaan (menyelidiki sesuatu yang berhubungan dengan IPA/Biologi). Kata laboratorium berasal dari kata laboratory, yang memiliki beberapa pengertian yaitu (Hadiat, 2008:109):
1) Tempat yang dilengkapi peralatan untuk melangsungkan eksperimen didalam sains atau melakukan pengujian dan analisis.

2) Bangunan atau ruang yang dilengkapi peralatan untuk melangsungkan penelitian ilmiah ataupun praktek pembelajaran bidang sains.

3) Tempat memproduksi bahan kimia atau obat.

4) Tempat kerja untuk melangsungkan penelitian ilmiah.

5) Ruang kerja seorang ilmuwan dan tempat menjalankan eksperimen bidang studi sains (kimia, IPA/Biologi)

$$
\text { Hadiat Moedjadi }
$$

mendefinisikan laboratorium adalah:

Prasarana, sarana dan mekanisme kerja yang menunjang secara unit satu atau lebih dari dharma sekolah dan atau madrasah (pendidikan dan pengajaran, penelitian serta pengabdian kepada masyarakat) melalui pengalaman langsung dalam membentuk keterampilan pemahaman, dan wawasan dalam pendidikan dan pengajaran, dalam pengembangan ilmu dan teknologi, serta pengabdian kepada masyarakat luas.

Menurut Moedjadi (dalam Rufiati, 2011: 87), laboratorium adalah "tempat dimana percobaan dan penyelidikan dilakukan. Tempat ini dapat merupakan suatu ruangan tertutup, kamar atau ruang terbuka". Dalam buku petunjuk pengelolaan laboratorium IPA SMA yang diterbitkan oleh Departemen Pendidikan dan Kebudayaan (1999:98), laboratorium adalah "tempat bekerja untuk mengadakan percobaan atau penyelidikan dalam bidang ilmu tertentu, seperti IPA/Biologi, kimia, dsb.

\subsubsection{Kompetensi Guru \\ Pengertian Kompetensi}

Kompetensi adalah: "kewenangan, kekuasaan untuk menentukan atau memutuskan suatu hal". Pengertian dasar kompetensi adalah kemampuan atau kecakapan. Kemampuan dan kecakapan seorang guru dalam melaksanakan sesuatu diperolehnya melalui suatu pendidikan tertentu. 
Kompetensi guru dalam pendidikan IPA berarti kemampuan guru dalam melaksanakan profesi keguruannya dalam kegiatan pendidikan IPA. Menurut Undang-Undang No 14 tahun 2005 tentang guru dan dosen disbeutkan terdapat 4 jenis kompetensi yang harus dimiliki oleh seorang guru: "Kompetensi guru sebagaimana dimaksud dalam Pasal 8 meliputi kompetensi pedagogik, kompetensi kepribadian, kompetensi sosial, dan kompetensi profesional yang diperoleh melalui pendidikan profesi."

Menurut Peraturan Menteri Pendidikan Nasional Republik Indonesia Nomor 16 Tahun 2007 Tentang Standar Kualifikasi Akademik dan Kompetensi Guru, adapun macammacam kompetensi yang harus dimiliki oleh tenaga guru antara lain: kompetensi pedagogik, kepribadian, profesional dan sosial yang diperoleh melalui pendidikan profesi. Keempat kompetensi tersebut terintegrasi dalam kinerja guru.

\section{Kompetensi Pedagogik}

Kompetensi pedagogik meliputi pemahaman guru terhadap peserta didik, perancangan dan pelaksanaan pembelajaran, evaluasi hasil belajar, serta pengembangan peserta didik untuk mengaktualisasikan berbagai potensi yang dimilikinya. Secara rinci setiap subkompetensi dijabarkan menjadi indikator esensial sebagai berikut;

a) Memahami peserta didik secara mendalam memiliki indikator esensial: memahami peserta didik dengan memanfaatkan prinsip-prinsip perkembangan kognitif; memahami peserta didik dengan memanfaatkan prinsip-prinsip kepribadian; dan mengidentifikasi bekal ajar awal peserta didik.

b) Merancang pembelajaran, termasuk memahami landasan pendidikan untuk kepentingan pembelajaran memiliki indikator esensial: memahami landasan kependidikan; menerapkan teori belajar dan pembelajaran; menentukan strategi pembelajaran berdasarkan karakteristik peserta didik, kompetensi yang ingin dicapai, dan materi ajar; serta menyusun rancangan pembelajaran berdasarkan strategi yang dipilih. c) Melaksanakan pembelajaran memiliki indikator esensial: menata latar (setting) pembelajaran; dan melaksanakan pembelajaran yang kondusif.

d) Merancang dan melaksanakan evaluasi pembelajaran memiliki indikator esensial: merancang dan melaksanakan evaluasi (assessment) proses dan hasil belajar secara berkesinambungan dengan berbagai metode; menganalisis hasil evaluasi proses dan hasil belajar untuk menentukan tingkat ketuntasan belajar (mastery learning); dan memanfaatkan hasil penilaian pembelajaran untuk perbaikan kualitas program pembelajaran secara umum.

\section{Kompetensi Kepribadian}

Kompetensi kepribadian merupakan kemampuan personal yang mencerminkan kepribadian yang mantap, stabil, dewasa, arif, dan berwibawa, menjadi teladan bagi peserta didik, dan berakhlak mulia. Secara rinci subkompetensi tersebut dapat dijabarkan sebagai berikut:

a) Kepribadian yang mantap dan stabil memiliki indikator esensial: bertindak sesuai dengan norma hukum; bertindak sesuai dengan norma sosial; bangga sebagai guru; dan memiliki konsistensi dalam bertindak sesuai dengan norma.

b) Kepribadian yang dewasa memiliki indikator esensial: menampilkan kemandirian dalam bertindak sebagai pendidik dan memiliki etos kerja sebagai guru.

c) Kepribadian yang arif memiliki indikator esensial: menampilkan tindakan yang didasarkan pada kemanfaatan peserta didik, sekolah, dan masyarakat serta menunjukkan keterbukaan dalam berpikir dan bertindak.

\section{Kompetensi Sosial}

Kompetensi sosial merupakan kemampuan guru untuk berkomunikasi dan bergaul secara efektif dengan peserta didik, sesama pendidik, tenaga kependidikan, orang tua/wali peserta didik, dan masyarakat sekitar. Kompetensi ini memiliki subkompetensi dengan indikator esensial sebagai berikut: 
a) Mampu berkomunikasi dan bergaul secara efektif dengan peserta didik memiliki indikator esensial: berkomunikasi secara efektif dengan peserta didik.

b) Mampu berkomunikasi dan bergaul secara efektif dengan sesama pendidik dan tenaga kependidikan.

c) Mampu berkomunikasi dan bergaul secara efektif dengan orang tua/wali peserta didik dan masyarakat sekitar.

\section{Kompetensi Profesional}

Kompetensi profesional merupakan penguasaan materi pembelajaran secara luas dan mendalam, yang mencakup penguasaan materi kurikulum mata pelajaran di sekolah dan substansi keilmuan yang menaungi materinya, serta penguasaan terhadap struktur dan metodologi keilmuannya. Setiap subkompetensi tersebut memiliki indikator esensial sebagai berikut:

a) Menguasai substansi keilmuan yang terkait dengan bidang studi memiliki indikator esensial: memahami materi ajar yang ada dalam kurikulum sekolah; memahami struktur, konsep dan metode keilmuan yang menaungi atau koheren dengan materi ajar; memahami hubungan konsep antar mata pelajaran terkait; dan menerapkan konsep-konsep keilmuan dalam kehidupan sehari-hari.

b) Menguasai struktur dan metode keilmuan memiliki indikator esensial menguasai langkah-langkah penelitian dan kajian kritis untuk memperdalam pengetahuan/materi bidang studi.

\subsection{Kerangka Berfikir}

\subsubsection{Hubungan antara Penggunaan Laboratorium dengan Hasil Belajar Siswa \\ Komponen lain yang cukup penting} dalam proses belajar adalah media. Kedudukan media pembelajaran ini tidak hanya sekedar alat bantu mengajar, tetapi juga merupakan salah satu cara untuk memotivasi dan berkomunikasi dengan siswa agar lebih efektif. Salah satunya adalah media Laboratorium IPA pada Sekolah Menegah Atas terdiri dari fisika dan biologi, serta kimia dasar. IPA/Biologi yang merupakan bagian dari IPA merupakan ilmu yang empiris. Segala prinsip dan sifat-sifatnya dipelajari melalui percobaan terhadap gejala-gejala alam. Dari hasil pengamatan gejala-gejala alam itu lalu disusun teori, dan teori itu selalu diuji kebenarannya apakah sesuai dengan pengalaman atau tidak. Untuk pengujian tersebut diperlukan ruangan khusus yang memang disediakan tempat untuk pengujian atau praktikum yang biasa disebut dengan laboratorium.

Dengan demikian diduga penggunaan laboraorium memiliki hubungan dengan hasil belajar siswa.

\subsubsection{Hubungan antara Kompetensi Guru dengan Hasil Belajar Siswa}

Guru merupakan salah satu komponen terhadap terciptanya proses dan hasil belajar yang berkualitas. Karena guru itu bukan hanya mengajar atau menyampaikan macam-macam ilmu pengetahuan, tetapi juga melaksanakan tugas mendidik, maka calon guru harus dipersiapkan melalui pendidikan professional di lembaga pendidikan guru. Dengan begitu guru sebagai pengajar atau pendidik, merupakan salah satu faktor penentu keberhasilan setiap usaha pendidikan dengan pengajaran. Sehingga tinggi rendahnya hasil belajar yang dicapai oleh siswa tergantung pada kompetensi profesionalisme yang dimiliki oleh guru.

Berdasarkan uraian di atas, maka diduga kompetensi guru memiliki hubungan dengan hasil belajar siswa.

\subsubsection{Hubungan antara Penggunaan Lab IPA dan Kompetensi Guru dengan Hasil Belajar Siswa \\ Dalam usaha meningkatan mutu} pendidikan, guru mempunyai peranan yang sangat penting dalam merealisasikan tujuan pendidikan nasional. Guru adalah ujung tombak kegiatan pengajaran di sekolah yang langsung berhadapan dengan peserta didik. Tanpa adanya peranan guru maka kegiatan Pembelajaran tidak akan sukses. Mengajar adalah membimbing kegiatan siswa, mengatur dan mengorganisasikan lingkungan yang ada disekitar siswa sehingga dapat mendorong dan menumbuhkan semangat siswa untuk melakukan kegiatan belajar, terutama sekali 
untuk mata pelajaran IPA. Mengajar adalah tugas yang begitu kompleks dan maha sulit, terutama sekali untuk guru mata pelajaran IPA, sehingga tidak dapat dilakukan dengan baik oleh seorang guru tanpa persiapan. Perencanaan pengajaran, pelaksanaan kegiatan belajar mengajar dan kegiatan evaluasi pengajaran merupakan serangkaian kegiatan dalam mengelola pembelajaran yang dikuasai dan dimiliki oleh seorang guru merupakan bagian dari kompetensi guru itu sendiri. Beranjak dari kompetensi inilah guru akan mengetahui apa yang harus dijalankannya, baik dalam perencanaan, pelaksanaan, maupun evaluasi berdasarkan teori yang diperoleh dari lembaga pendidikan yang pernah ditempuhnya. Oleh karena itu, kompetensi adalah sesuatu yang mutlak dimiliki oleh setiap guru dalam kegiatan pengelolaan pembelajaran.

Alur pikir kerangka penelitian digambarkan pada gambar 1 .

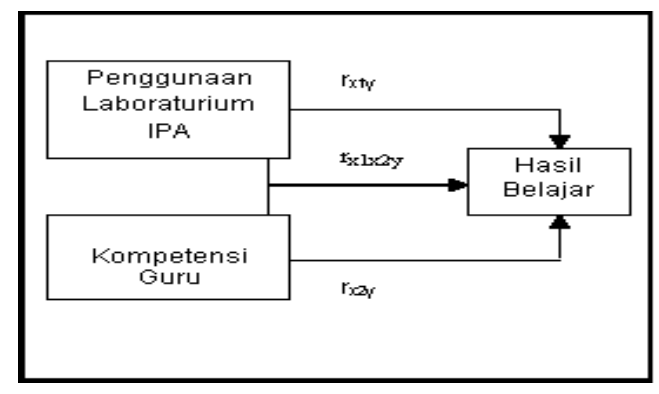

Gambar 1 Alur Pikir Kerangka Penelitian

\subsection{Hipotesis Penelitian}

Rumusan hipotesis dalam penelitian ini sebagai berikut :

1. Ho : Tidak terdapat hubungan yang signifikan antara penggunaan Laboratorium IPA dengan hasil belajar.

$\mathrm{Ha}$ : Terdapat hubungan yang signifikan antara penggunaan Laboratorium IPA dengan hasil belajar.

2. Ho : Tidak terdapat hubungan yang signifikan antara kompetensi guru dengan hasil belajar.

$\mathrm{Ha}$ : Terdapat hubungan yang signifikan antara kompetensi guru dengan hasil belajar.

3. Ho : Tidak terdapat hubungan yang signifikan antara penggunaan Laboratorium IPA dan kompetensi guru secara bersama-sama dengan hasil belajar.

$\mathrm{Ha}$ : Terdapat hubungan yang signifikan antara penggunaan Laboratorium IPA Dan kompetensi guru secara bersama-sama dengan hasil belajar.

\section{METODOLOGI PENELITIAN}

\subsection{Waktu dan Tempat Penelitian}

Penelitian ini dilakukan di SMAN 1 Cibungbulang Kecamatan Kabupaten Bogor, dimulai dari bulan Oktober 2013 sampai dengan Desember 2013

\subsection{Metode Penelitian}

Metode penelitian yang digunakan adalah metode penelitian kuantitatif dengan pendekatan korelasional. Metode survey adalah penelitian yang dilakukan pada populasi tetapi data yang dipelajari adalah data sampel yang diambil dari populasi. Sedangkan penelitian dengan pendekatan korelasi bertujuan menguji hipotesis yang menyatakan adanya hubungan antara variabel bebas dengan variabel terikat. Metode pengumpulan data untuk mendapatkan data primer di lapangan dengan menggunakan hasil test dan angket dalam bentuk kuesioner. Dalam kuesioner tersebut tersusun beberapa butir pernyataan yang berkaitan dengan masing-masing variabel dan indikator variabel penelitian. Unit analisis dalam penelitian ini adalah para siswa di SMAN Cibungbulang Kecamatan Cibungbulang Kabupaten Bogor. Pada penelitian ini terdapat satu variabel terikat yaitu Hasil Belajar ( $Y$ ) dan dua variabel bebas yaitu Penggunaan Laboratorium IPA $\left(\mathrm{X}_{1}\right)$ dan kompetensi guru $\left(\mathrm{X}_{2}\right)$. Konstelasi masing-masing variabel dapat dilihat pada gambar 2 .

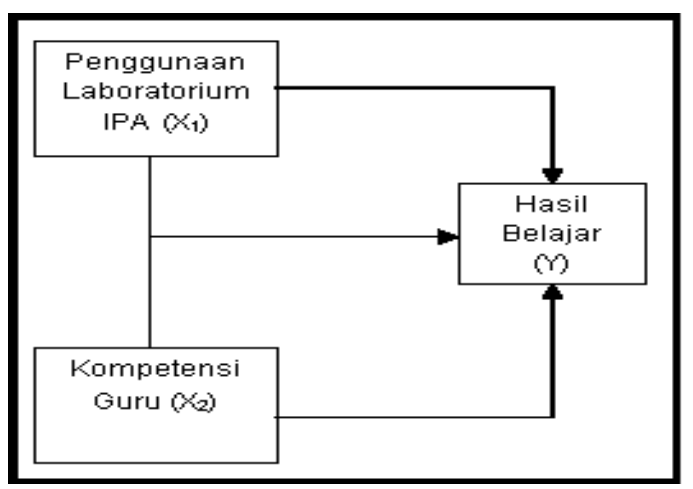


Gambar 2 Konstelasi Variabel Penelitian

\subsection{Populasi dan Sampel}

Populasi penelitian ini adalah seluruh siswa pada program IPA di SMAN Cibungbulang yang terdiri dari kelas $\mathrm{XI}$ dan kelas XII yang berjumlah 301 .

Sampel adalah sebagian atau wakil populasi yang diteliti. Populasi terjangkau dari penelitian ini adalah seluruh siswa pada program IPA di SMAN Cibungbulang yang terdiri dari kelas $\mathrm{XI}$ dan kelas XII yang berjumlah 301 . Adapun proporsi yang penulis pergunakan adalah seperti yang dikemukakan oleh Suharsimi Arikunto (2006:134) bahwa apabila subyeknya kurang dari 100 , lebih baik diambil semua sehingga penelitiannya merupakan penelitian populasi, selanjutnya jika jumlah subyeknya besar dapat diambil antara $10-15 \%$ atau $20-25 \%$ atau lebih.

Jadi dari populasi yang berjumlah 301 siswa kelas IPA di SMAN Cibungbulang, diambil sebanyak $15 \%$, sehingga yang menjadi sampel penelitian sebanyak 45 siswa yang diambil dari kelas XI IPA. Teknik penentuan sampel di kelas XI IPA tersebut dilakukan dengan cara pengundian (random) Uji coba instrumen dilaksanakan di SMAN Cibungbulang Kecamatan Cibungbulang Kabupaten Bogor dengan responden berjumlah 30 orang siswa selain sampel penelitian.

\subsection{Instrumen Penelitian}

Untuk memperoleh data tentang ketiga varibel maka disusun instrumen penelitian melalui beberapa tahap yaitu:1) mengkaji semua teori yang berkaitan dengan variabelvariabel penelitian, 2) menyusun indikator dari setiap variabel penelitian, 3) menyusun kisikisi, 4) menyusun butir-butir pernyataan dan menetapkan skala pengukuran, 5) uji coba instrumen, 6) analisis butir soal dengan menguji validitas dan reliabilitas. Instrumen yang digunakan dalam penelitian ini dapat dilihat pada tabel 1 .

Tabel 1 Instrumen Penelitian

\begin{tabular}{cc}
\hline Variabel & Instrumen \\
\hline Penggunaan & Angket/Kuesioner \\
Laboratorium & \\
IPA/Biologi & \\
\hline
\end{tabular}

\begin{tabular}{cc}
\hline Kompetensi Guru & Angket/Kuesioner \\
Hasil Belajar IPA & Tes Pilihan ganda Hasil \\
& Belajar \\
\hline
\end{tabular}

\subsection{Teknik Analisis Data}

Dilaksanakan dengan langkah-langkah:

1) Analisis deskriptif, meliputi pencarian nilai: mean, media, modus, frekuensi, simpangan baku, dan varians.

2) Analisis inferensial untuk menguji hipotesis, meliputi: uji korelasi sederhana, uji korelasi parsial, dan uji korelasi ganda.

\section{Uji Korelasi Sederhana}

Teknik korelasi sederhana yang digunakan adalah Product moment. Hal ini dimaksudkan untuk melihat hubungan antara variabel-variabel bebas dengan variabel terikat. Korelasi sederhana ini untuk menguji hipotesis pertama dan hipotesis kedua, dilanjutkan dengn uji $t$ untuk melihat apakah terjadi hubungan antara variabel yang diteliti.

\section{Uji Korelasi Parsial}

Uji Korelasi Parsial digunakan untuk mengetahui hubungan antara variabel bebas dengan variabel terikat dan sebaliknya.

\section{Uji Korelasi Ganda}

Uji ini dimaksudkan untuk menguji hipotesis ketiga, yang bertujuan untuk melihat apakah terdapat korelasi yang berarti apabila kedua variabel bebas secara bersama-sama dikorelasikan dengan variabel terikat. Selanjutnya digunakan uji $F$ untuk menentukan apakah terjadi hubungan atau tidak diantara variabel yang diteliti.

\section{HASIL DAN PEMBAHASAN}

Sebagaimana dikemukakan sebelumnya bahwa tujuan umum penelitian ini adalah menentukan ada atau tidaknya hubungan positif antara penggunaan Laboratorium IPA dan kompetensi guru dengan hasil belajar, baik secara sendiri maupun secara bersama. Untuk mencapai tujuan penelitian tersebut, dalam bagian atau bab ini akan disajikan secara berurutan hasil penelitian yang membahas masalah-masalah pokok yang berkenaan dengan (1) deskripsi data, (2) pengujian persyaratan analisis, dan (3) pengujian hipotesis. Disamping itu, dalam 
bagian ini akan disajikan pula pembahasan hasil penelitian. Dengan demikian secara garis besar laporan hasil penelitian ini dibedakan atas tiga bagian pokok yaitu: deskripsi data, pengujian persyaratan analisis dan pengujian hipotesis.

\subsection{Deskripsi Data}

Data yang dijadikan dasar deskripsi hasil penelitian ini adalah skor angket penggunaan laboratorium IPA $\left(\mathrm{X}_{1}\right)$ dan kompetensi guru $\left(\mathrm{X}_{2}\right)$, serta skor hasil tes IPA (Y). Data tersebut diolah dengan menggunakan teknik statistik deskriptif yang terdiri dari rata-rata (mean), nilai tengah (median), nilai yang sering muncul (modus), simpangan baku (standar deviasi), distribusi frekuensi (varian), nilai minimum dan maksimum, rentang antara nilai minimum dan maksimum (range), keragaman data (varians sampe/), total nilai (sum), banyak kelas dan rentang kelas yang disertai grafik histogram dari ketiga variabel penelitian:

\subsubsection{Deskripsi Data Penggunaan Laboratorium IPA $\left(\mathbf{X}_{1}\right)$ \\ Data penggunaan laboratorium IPA} berdasarkan hasil pengolahan data yang diperoleh responden. Diketahui bahwa pernyataan responden dalam menjawab butir pernyataan memperoleh jumlah skor $=2.943$, skor tertinggi $=79$ dan skor terendah $=53$ dengan rentang skor 26 . Kemudian dari hasil perhitungan diperoleh rata-rata skor empirik (mean) sebesar $=67,4$ dengan nilai median 65. Selanjutnya diperoleh nilai atau skor yang paling sering muncul (modus) adalah $=74$. Selain itu diperoleh varians sampel sebesar $=$ 75,06 dan standar deviasi (SD) sebesar = 8,66 .

Data tersebut, disajikan dalam bentuk histogram pada gambar 3 .

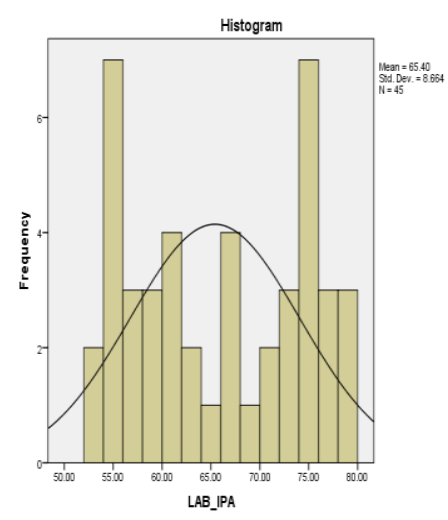

Gambar 3 Histogram Data Penggunaan Laboratorium IPA $\left(\mathrm{X}_{1}\right)$

Berdasarkan hasil perhitungan skor, nilai rata-rata hitung, median, modus serta sebaran distribusi frekuensi dan histogram di atas, dapat diperoleh gambaran bahwa data penggunaan laboratorium IPA mempunyai distribusi yang simetris. Demikian juga jika melihat nilai rata-rata penggunaan laboratorium IPA lebih besar dari nilai tengah teoritis, hal ini dapat ditafsirkan bahwa penggunaan laboratorium IPA termasuk kategori sudah baik.

\subsubsection{Deskripsi Data Kompetensi Guru $\left(X_{2}\right)$}

Data kompetensi Guru berdasarkan hasil pengolahan data yang diperoleh dari responden. Diketahui bahwa pernyataan responden dalam menjawab butir pernyataan memperoleh jumlah skor $=2,698$, skor tertinggi $=76$ dan skor terendah $=47$ dengan rentang skor 29. Kemudian dari hasil perhitungan diperoleh rata-rata skor empirik (mean) sebesar $=59,95$ dengan nilai median 59. Selanjutnya diperoleh nilai atau skor yang paling sering muncul (modus) adalah $=50$. Selain itu diperoleh varians sampel sebesar $=$ 69,36 dan standar deviasi (SD) sebesar $=$ 8,32 .

Data tersebut, disajikan dalam bentuk histogram pada gambar 4 . 


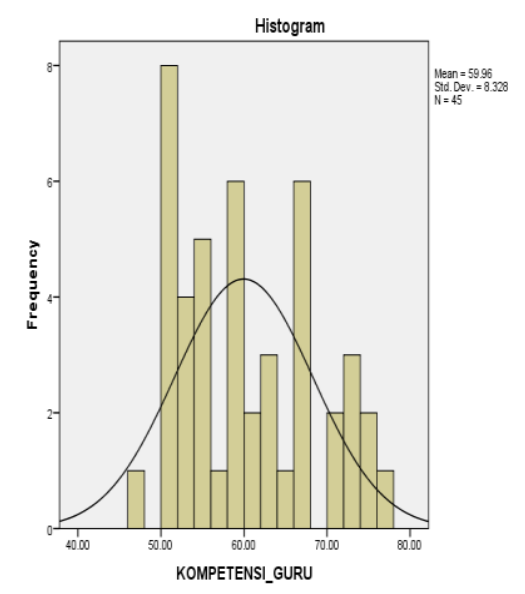

Gambar 4 Histogram Data Kompetensi Guru $\left(\mathrm{X}_{2}\right)$

\subsubsection{Deskripsi Data Hasil Belajar ( $Y$ )}

Data skor hasil tes berdasarkan hasil pengolahan data yang diperoleh dari jawaban responden disajikan dalam deskripsi histogram pada gambar 5 .

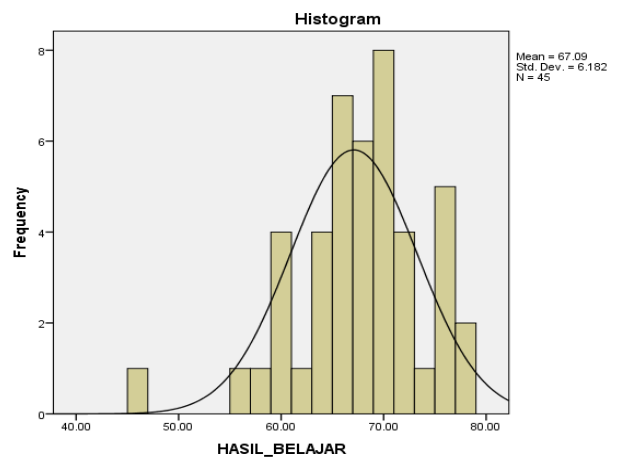

Gambar 5 Histogram Data Hasil Belajar (Y)

Berdasarkan hasil perhitungan nilai rata-rata hitung, median, modus serta sebaran distribusi frekuensi dan histogram di atas, dapat diperoleh gambaran bahwa data hasil belajar mempunyai distribusi yang simetris. Demikian juga jika melihat nilai rata-rata hasil belajar lebih besar dari nilai tengah teoritis, hal ini dapat ditafsirkan bahwa hasil belajar termasuk kategori sudah baik.

\subsection{Pengujian Prasyarat Analisis}

\subsubsection{Uji Normalitas Galat Taksiran}

Pengujian normalitas galat taksiran regresi $Y$ atas $X$ dimaksudkan untuk menguji apakah galat taksiran regresi $Y$ atas $X_{1}$ berdistribusi normal atau tidak. Pengujian normalitas galat taksiran untuk masing-masing variabel penelitian dilakukan dengan uji Kolmogorov-Smirnov. Ketentuan pengujiannya adalah galat taksiran adalah:
- Jika nilai signifikansi $(p)<0,05=$ Data berdistribus tidak normal.

- Jika nilai signifikansi $(p)>0,05=$ Data berdistribusi normal.

Rangkuman hasil pengujian normalitas galat taksiran dapat dilihat pada tabel 2 .

Tabel 2 Rangkuman Hasil Pengujian Normalitas Galat Taksiran

\begin{tabular}{cccc}
\hline $\begin{array}{c}\text { Galat } \\
\text { Taksiran }\end{array}$ & $\begin{array}{c}\text { Nilai } \\
\text { Probabilitas }\end{array}$ & $\begin{array}{c}\text { Nilai } \\
\text { Asymp. } \\
\text { Sig }\end{array}$ & Kesimpulan \\
\hline Y atas $\mathrm{X}_{1}$ & 0,409 & 0,05 & NORMAL \\
Y atas $\mathrm{X}_{2}$ & 0,492 & 0,05 & NORMAL \\
\hline
\end{tabular}

Berdasarkan tabel 2, pada baris Asymp. Sig. (2-tailed) diperoleh nilai signifikansi variabel penggunaan laboratorium IPA $\left(\mathrm{X}_{1}\right)$ sebesar 0,409 , dengan nilai signifikansi > 0,05 , berdasarkan probabilitas. Jika probabilitas $>0,05$, maka dapat disimpulkan bahwa data variabel penggunaan laboratorium IPA berdistribusi normal.

Berdasarkan tabel 2, pada baris Asymp. Sig. (2-tailed) diperoleh nilai signifikansi variabel kompetensi guru $\left(X_{2}\right)$ sebesar 0,492 , dengan nilai signifikansi $>0,05$, berdasarkan probabilitas. Jika probabilitas $>0,05$, maka dapat disimpulkan bahwa data variabel kompetensi guru berdistribusi normal.

\subsubsection{Uji Homogenitas}

Pengujian homogenitas varians data hasil belajar atas data penggunaan Lab IPA dilakukan dengan menggunakan uji Levene, dengan asumsi jika:

- Sign value > 0,05, maka Ha diterima, artinya data bersifat homogen

- Sign value <0,05, maka Ho diterima, artinya data tidak bersifat homogen

Rangkuman uji homogenitas data dengan menggunakan uji Bartlett dapat dilihat pada tabel 3.

Tabel 3 Rangkuman Uji Homogenitas Data dengan Menggunakan Uji Bartlett

\begin{tabular}{cccc}
\hline Variabel & $\begin{array}{c}\text { Sign } \\
\text { Value }\end{array}$ & $\begin{array}{c}\text { Asymp. } \\
\text { Sig }\end{array}$ & Kesimpulan \\
\hline $\mathrm{Y}$ atas $\mathrm{X}_{1}$ & 0,120 & 0,05 & Homogen \\
$\mathrm{Y}$ atas $\mathrm{X}_{2}$ & 0,879 & 0,05 & Homogen \\
\hline
\end{tabular}


Berdasarkan hasil pengujian diperoleh nilai Sign value $=0,120$. Dengan demikian Sign value $>0,05$ atau $0,120>0,05$. Hal tersebut bermakna bahwa kelompok data hasil belajar $(\mathrm{Y})$ atas penggunaan laboratorium IPA $\left(\mathrm{X}_{1}\right)$ berasal dari populasi yang homogen.

Selanjutnya, berdasarkan hasil pengujian diperoleh nilai Sign value $=0,879$. Dengan demikian Sign value $>0,05$ atau $0,879>0,05$. Hal tersebut bermakna bahwa kelompok data hasil belajar $(\mathrm{Y})$ atas kompetensi guru $\left(\mathrm{X}_{1}\right)$ berasal dari populasi yang homogen.

\subsubsection{Uji Multikolinearitas}

Uji Multikolinearitas dilakukan dengan melihat nilai VIF dan tolerance hasil pengolahan dengan program SPSS 21 menghasilkan perhitungan yang dapat dilihat pada tabel 4 .

Tabel 4 Rangkuman Hasil Uji Multikolinearitas

\begin{tabular}{ccc}
\hline Variabel & VIF & Kesimpulan \\
\hline $\begin{array}{c}\text { Penggunaan } \\
\text { LAB IPA } \\
\text { Kompetensi } \\
\text { Guru }\end{array}$ & 1,126 & Memenuhi \\
\hline
\end{tabular}

Hasil yang baik diperoleh jika nilai tolerance mendekati angka satu dan nilai VIF berada di seputar 1 dan maksimal 10 . Berdasarkan hasil uji tersebut maka data nilai VIF untuk variabel penggunaan Laboratorium IPA adalah 1,126 dan untuk variabel kompetensi guru adalah 1,126. Dengan demikian kedua variabel memenuhi persayaratan multikolinearitas.

\subsubsection{Uji Autokorelasi}

Uji Durbin-Watson hasil pengolahan SPSS Ver 21 digunakan untuk mengetahui terpenuhi tidaknya asumsi non autokorelasi. Hasil pengujian data diperoleh nilai Durbin Watson menunjukkan nilai 2,110. Angka ini lebih besar dari 1 dan lebih kecil dari 3 . Secara ringkas $1<2,110<3$. Karena nilai Durbin Watson berada diantara batasan autokorelasi maka kita dapat menyimpulkan bahwa salah satu syarat uji regresi linier berganda telah terpenuhi karena tidak terjadi autokorelasi.

\subsection{Pengujian Hipotesis}

\subsubsection{Hubungan antara Penggunaan Laboraorium IPA dengan Hasil Belajar Siswa}

Hasil perhitungan korelasi dalam penelitian ini adalah terdapat hubungan positif antara penggunaan laboratorium IPA $\left(\mathrm{X}_{1}\right)$ dengan hasil belajar $(Y)$ sebesar 0,436 yang merupakan nilai korelasi antara penggunaan laboratorium IPA $\left(\mathrm{X}_{1}\right)$ dengan hasil belajar $(\mathrm{Y})$. Nilai korelasi tersebut mengindikasikan bahwa terdapat hubungan yang positif antara kedua variabel. Sedangkan nilai $R$ square atau koefisien determinasi adalah sebesar 0,190 menunjukkan bahwa kontribusi penggunaan laboratorium IPA terhadap hasil belajar IPA adalah sebesar $19 \% \quad(0,4362 \times 100 \%)$, sedangkan sisanya $81 \%$ hasil belajar dipengaruhi oleh faktor lain yang tidak dianalisis dalam penelitian ini.

Pengambilan keputusan dalam penelitian ini yaitu:

- Jika $\mathrm{F}$ hitung $\leq \mathrm{F}$ tabel atau probabilitas $\geq$ 0,05 maka Ho diterima

- Jika $\mathrm{F}$ hitung $\geq \mathrm{F}$ tabel atau probabilitas $\leq$ 0,05 maka Ho ditolak

Dari hasil perhitungan diperoleh nilai $\mathrm{F}$ hitung adalah 10,09 dengan taraf signifikansi sebesar 0,05 . Nilai $F(1 / 43)$ tabel dengan $N=45$ dan taraf signifikansi 0,05 diperoleh 4,07. Dengan demikian F hitung $10.09>4,07$, sehingga Ho ditolak serta dapat dinyatakan regresi layak dengan kepercayaan 0,05.

Berdasarkan perhitungan diperoleh nilai sig. 0,003 itu berarti probabilitas 0,003<0,05 maka Ho ditolak dan Ha diterima. Sehingga dapat dinyatakan bahwa kesimpulannya regresi layak dengan kepercayaan 0,05 , serta dapat dipakai untuk memprediksi penggunaan laboratorium IPA.

Selanjutnya berdasarkan perhitungan dengan bantuan SPSS 21, diperoleh nilai $t$ hitung sebesar 3,176 , sedangkan nilai $t$ tabel untuk $\mathrm{N}=45$ adalah 2,00, dengan pengujian 2 sisi pada taraf signifikansi 0,05. Jika dibandingkan antara $\mathrm{t}$ hitung dengan $\mathrm{t}$ tabel, maka $\mathrm{t}$ hitung $3,176>$ dari $\mathrm{t}$ tabel 2,00. Karena nilai $t$ hitung lebih besar dari nilai $t$ tabel maka artinya Ho ditolak dan Ha diterima. Dengan kata lain dapat disimpulkan "Terdapat 
hubungan yang signifikan antara penggunaan Laboratorium IPA dengan hasil belajar".

Persamaan garis regresinya adalah sebagai berikut:

$Y=\alpha+\beta(X)$

$Y=46,745+0,311\left(X_{1}\right)$

Keterangan:

$Y=$ Hasil Belajar

$X=$ Penggunaan Laboratorium IPA

Dari persamaan garis regresi menggambarkan bahwa nilai alpha (a) merupakan angka konstan yang dinyatakan dengan nilai dalam keadaan konstan sebesar 46,745. Nilai beta ( $\beta$ ) merupakan penggunaan Laboratorium IPA sebesar 0.311, menyatakan bahwa setiap peningkatan nilai variabel penggunaan Laboratorium IPA sebesar satu satuan maka akan memberikan kontribusi terhadap variabel hasil belajar sebesar 0,311 satuan, dengan asumsi variabel kompetensi guru konstan.

\subsubsection{Hubungan antara Kompetensi Guru dengan Hasil Belajar}

Hasil perhitungan korelasi dalam penelitian ini adalah terdapat hubungan positif antara kompetensi guru $\left(X_{2}\right)$ dengan hasil belajar $(Y)$ sebesar 0,23 . Berdasarkan hasil perhitungan diperoleh nilai $\mathrm{R}$ sebesar 0,231 yang merupakan nilai korelasi antara kompetensi guru $\left(\mathrm{X}_{2}\right)$ dengan hasil belajar $(\mathrm{Y})$. Nilai korelasi tersebut mengindikasikan bahwa terdapat hubungan yang positif antara kedua variabel. Sedangkan nilai $R$ square atau koefisien determinasi adalah sebesar 0,053 menunjukkan bahwa kontribusi kompetensi guru terhadap hasil belajar adalah sebesar $5,3 \%(0,2312 \times 100 \%)$, sedangkan sisanya $94,7 \%$ hasil belajar dipengaruhi oleh faktor lain yang tidak dianalisis dalam penelitian ini.

\footnotetext{
Pengambilan keputusan dalam penelitian ini yaitu:

- Jika $\mathrm{F}$ hitung $\leq \mathrm{F}$ tabel atau probabilitas $\geq$ 0,05 maka Ho diterima

- Jika $\mathrm{F}$ hitung $\geq \mathrm{F}$ tabel atau probabilitas $\leq$ 0,05 maka Ho ditolak
}

Dari hasil perhitungan diperoleh nilai $F$ hitung 6,422 dengan taraf signifikansi sebesar 0,05. Nilai $F(1 / 43)$ tabel dengan $N=45$ dan taraf signifikansi 0,05 diperoleh 4,07. Dengan demikian $\mathrm{F}$ hitung $6,422>4,07$, sehingga $\mathrm{Ho}$ ditolak serta dapat dinyatakan regresi layak dengan kepercayaan 0,05.

Berdasarkan perhitungan diperoleh nilai sig. yaitu 0,027 itu berarti probabilitas $0,027<$ 0,05 maka Ho ditolak dan $\mathrm{Ha}$ diterima. Sehingga dapat dinyatakan bahwa kesimpulannya regresi layak dengan kepercayaan 0,05 , serta dapat dipakai untuk memprediksi kompetensi guru.

Selanjutnya berdasarkan perhitungan dengan bantuan SPSS 21, diperoleh nilai $t$ hitung adalah sebesar 2,556 , sedangkan nilai t tabel untuk $\mathrm{N}=45$ adalah 2,00 , dengan pengujian 2 sisi pada taraf signifikansi 0,05. Jika dibandingkan antara $\mathrm{t}$ hitung dengan $\mathrm{t}$ tabel, maka t hitung 2,556 > dari t tabel 2,00. Karena nilai $\mathrm{t}$ hitung lebih besar dari nilai $\mathrm{t}$ tabel maka artinya Ho ditolak dan Ha diterima. Dengan kata lain dapat disimpulkan "Terdapat hubungan yang signifikan antara kompetensi guru dengan hasil belajar".

Persamaan garis regresinya adalah sebagai berikut:

$Y=\alpha+\beta(X)$

$Y=56,811+0,171\left(X_{1}\right)$

Keterangan:

$Y=$ Hasil Belajar

$X=$ Kompetensi Guru

Dari persamaan garis regresi menggambarkan bahwa nilai alpha $(\alpha)$ merupakan angka konstan yang dinyatakan dengan nilai dalam keadaan konstan sebesar 56,811 . Nilai beta ( $\beta$ ) merupakan koefisien kompetensi guru sebesar 0.171 , menyatakan bahwa setiap peningkatan nilai variabel kompetensi guru sebesar satu satuan maka akan memberikan kontribusi terhadap variabel hasil belajar sebesar 0,171 satuan, dengan asumsi variabel penggunaan laboratorium IPA konstan.

\subsubsection{Hubungan antara variabel \\ Penggunaan Laboratorium IPA dan Kompetensi Guru secara bersama- sama dengan Hasil Belajar}

Dari data diperoleh harga $\mathrm{R}$ atau $\mathrm{R}_{\mathrm{y}(1,2)}$ sebesar 0,445 , artinya penggunaan laboratorium IPA dan kompetensi guru secara bersama-sama memiliki hubungan positif terhadap hasil belajar sebesar 0,445. Koefisien determinasi ( $R$ square) $R_{2 y(1,2)}$ 
sebesar 0,198 berarti penggunaan laboratorium IPA dan kompetensi guru secara bersama-sama mampu mempengaruhi hasil belajar sebesar 19,8\%. Hal ini menunjukan masih ada $80,2 \%$ faktor atau variabel lain yang mempengaruhi hasil belajar, selain penggunaan laboratorium IPA dan kompetensi guru secara bersama-sama.

Berdasarkan hasil uji $\mathrm{F}$ diperoleh $\mathrm{F}$ hitung sebesar 5,191. Jika dibandingkan dengan Ftabel dengan df 2:44 sebesar 3,22 pada taraf signifikasi $5 \%$ maka Fhitung sebesar 5,191 lebih besar dari Ftabel sebesar 3,22 . Hal ini menunjukan bahwa terdapat hubungan yang positif dan signifikan antara penggunaan laboratorium IPA dan kompetensi guru secara bersama-sama terhadap hasil belajar.

Harga koefisien korelasi $\mathrm{R}_{\mathrm{y}(1,2)}$ sebesar 0,445 lebih besar dari rtabel sebesar 0,288, maka dapat disimpulkan hipotesis ketiga ( $\mathrm{Ha})$ diterima yaitu "Terdapat hubungan yang signifikan antara penggunaan Laboratorium IPA dan kompetensi guru secara bersamasama dengan hasil belajar".

Persamaan garis regresinya adalah sebagai berikut:

$Y=\alpha+\beta\left(X_{1}\right)+\beta\left(X_{2}\right)$

$Y=43,975+0,288+0,071$

Keterangan:

$Y=$ Hasil Belajar

$\mathrm{X}_{1}=$ Penggunaan laboratorium IPA

$\mathrm{X}_{2}=$ Kompetensi Guru

Dari persamaan garis regresi di atas menggambarkan bahwa alpha ( $\alpha$ ) merupakan angka konstan yang dinyatakan dengan nilai dalam keadaan konstan sebesar 43,975. Nilai Beta $(\beta) 1$ adalah koefisien penggunaan laboratorium IPA sebesar 0.288 dan Beta $(\beta) 2$ adalah koefisien kompetensi guru sebesar 0,071 . Menyatakan bahwa setiap peningkatan nilai variabel penggunaan Laboratorium IPA dan kompetensi guru secara bersama-sama sebesar satu satuan maka akan memberikan kontribusi terhadap variabel hasil belajar sebesar 43,975 satuan.
Adapun rangkuman hasil uji hipotesis, kontribusi, kesimpulan dan interprestasi disajikan dalam tabel 5.

\section{KESIMPULAN DAN SARAN}

\subsection{Kesimpulan}

Dari hasil analisis data didapatkan persamaan regresi yang terbentuk sebagai berikut :

1. Bahwa penggunaan laboratorium IPA berhubungan positif dengan hasil belajar. Besarnya kontribusi penggunaan laboratorium IPA tehadap hasil belajar yakni sebesar 19\%. Berdasarkan hasil perhitungan, setiap perubahan hasil belajar IPA pada kelas XI di SMAN 1 Cibungbulang Kabupaten Bogor sebesar satu (1) satuan ditentukan oleh penggunaan laboratorium IPA sebesar 0,311 satuan.

2. Bahwa kompetensi guru berhubungan positif dengan hasil belajar. Besarnya kontribusi kompetensi guru terhadap hasil belajar yakni sebesar 5,3\%. Berdasarkan hasil perhitungan, setiap perubahan hasil belajar IPA pada kelas XI di SMAN 1 Cibungbulang Kabupaten Bogor sebesar satu (1) satuan ditentukan oleh kompetensi guru sebesar 0,171 satuan.

3. Bahwa penggunaan laboratorium IPA dan kompetensi guru secara bersama-sama berhubungan positif dengan hasil belajar. Besarnya kontribusi penggunaan laboratorium IPA dan kompetensi guru secara simultan terhadap hasil belajar yakni sebesar 19,8\%. Dengan demikian perubahan hasil belajar IPA pada kelas XI di SMAN 1 Cibungbulang Kabupaten Bogor ditentukan oleh penggunaan laboratorium IPA dan kompetensi guru secara simultan sebesar 43,975 satuan.

\subsection{Saran}

Kesimpulan yang diperoleh dari penilitian ini dapat dijadikan masukan atau bahan evaluasi terhadap hal-hal yang terkait dengan variabel penelitian yaitu pemanfaatan laboratorium IPA da kompetensi guru. Beberapa hal yang perlu mendapat perhatian yaitu: 
Tabel 5 Rangkuman Hasil Uji Hipotesis, Kontribusi, Kesimpulan dan Interprestasi

\begin{tabular}{cccccc}
\hline Korelasi & $\mathrm{t}_{\text {hitung }}$ & $\mathrm{t}_{\text {tabel }}$ & Kesimpulan & Hipotesis & Kontribusi \\
\hline $\mathrm{X}_{1}$ dengan $\mathrm{Y}$ & 3,176 & 2,00 & Signifikan & Ha diterima & $19 \%$ \\
$\mathrm{X}_{2}$ dengan $\mathrm{Y}$ & 2,556 & 2,00 & Signifikan & Ha diterima & $5,3 \%$ \\
& $\mathrm{~F}_{\text {hitung }}$ & $\mathrm{F}_{\text {tabel }}$ & & & \\
\hline $\mathrm{X}_{1}+\mathrm{X}_{2}$ dengan $\mathrm{Y}$ & $\mathbf{5 , 1 9 1}$ & $\mathbf{3 , 2 2}$ & Signifikan & Ha diterima & $19,8 \%$ \\
\hline
\end{tabular}

1. Laboratorium IPA sebagai salah satu sarana belajar wajib bagi para siswa, khususnya siswa yang mengambil jurusan IPA, hendaknya harus terus dimanfaatkan, dirawat dan terus dipelihara. Karena keberadaa Lab IPA sangat membantu siswa dalam memahami konsep dan materi IPA.

2. Bagi para guru sebaiknya selalu meningkatkan kompetensinya, terutama dalam kemampuan mengajar agar dapat mengikuti kemajuan dan perkembangan pendidikan, terutama yang berhubungan dengan proses pembelajaran. Karena zaman akan terus berkembang dan kebutuhan akan ilmu dan teknologi kian meningkat. Sehingga dengan kompetensinya sebagai seorang guru akan mampu mengatasi berbagai masalah yang terjadi dalam masyarakat terutama dalam dunia pendidikan. Selain itu Bagi guru hendaknya selalu menciptakan situasi pembelajaran yang kondusif, sehingga suasana belajar akan lebih nyaman, dengan menggunakan metode yang sesuai dengan materi yang sedang dibahas. Dengan demikian siswa akan lebih memahami tentang materi yang sedang dipelajari. Selalu memperhatikan penggunaan metode pembelajaran yang bervariatif sesuai dengan tujuan pembelajaran, agar materi ajar dapat disampaikan dengan baik yang pada akhirnya tujuan pembelajaran akan tercapai sehingga hasil belajar lebih maksimal.

3. Agar hasil belajar siswa dapat lebih ditingkatkan maka para siswa hendaknya terus memperbaiki sikap serta memacu diri dalam belajar, karena dengan belajar maka cakrawala dunia akan terbuka lebar, dengan tidak lupa berdo'a kepada Allah, SWT.
4. Bagi pihak sekolah agar lebih memberikan perhatian pada kemampuan/kompetensi guru dengan cara memfasilitasi kegiatan peningkatan kemampuan profesionalisme guru melalui kegiatan pelatihan dsb.

5. Adanya penelitian lanjutan mengenai variabel kompetensi guru dan metode pembelajaran sehingga dapat ditemukan hal-hal yang lebih terperinci dan solusi yang lebih tepat bagaimana ketiga variabel tersebut di atas berpengaruh terhadap hasil belajar siswa.

\section{DAFTAR PUSTAKA}

Ahmadi, lif Khoiru dkk. (2011). Pembelajaran Akselerasi. Jakarta: Prestasi Pustaka

Amien, Moh. (1984). Buku Pedoman Praktikum Dan Manual Laboratorium Pendidikan IPA Umum (General Science). Jakarta: Departemen Pendidikan dan Kebudayaan

Arikunto, Suharsimi. (2006). Prosedur Penelitian Suatu Pendekatan Praktik Cet. XIII. Jakarta: PT Rineka Cipta.

Aunurrahman. (2009). Belajar dan Pembelajaran. Bandung: Alfabeta.

Depdikbud. (1999). Pengelolaan Laboratorium Sekolah dan Manual Alat IImu Pengetahuan Alam. Jakarta: Depdikbud

Depdiknas (1999). Pelatihan Manajemen Pendidikan bagi Kepala Sekolah Menengah Umum se-Indonesia di Surabaya. Jakarta : Depdikbud

Etna, Rufiati. (2011). Bagaimana Cara Mengelola Laboratorium. Bandung: Jaya Sheet 
Kertawidjaja, lon. dkk. (1990). Studi Pelaksanaan, Pengelolaan Laboratorium Pendidikan Sains, SMA di Provinsi Jawa Barat. Bandung: FPMIPA IKIP Bandung.

Koesmadji, W. dkk. (2004). Teknik Laboratorium. Bandung: FMIPA Universitas Pendidikan Indonesia.

KTSP. (2006). Standar Kompetensi dan Kompetensi Dasar IPA SMA. Jakarta: BSNP.

Lubis, Muchsin. dkk. (1993/1994). Pengelolaan Laboratorium IPA: Materi Pokok Modul Universitas Terbuka. Jakarta: Depdikbud.

Marno. (2010). Strategi dan Metode Pengajaran. Jogjakarta: Ar-Ruzz Media.

Moedjadi, Hadiat, dkk. (1978). Pengelolaan Laboratorium Sekolah Dan Manual Alat IImu Pengetahuan Alam. Jakarta: Depatemen Pendidikan dan Kebudayaan.

Poedjiadi, Anna. (1984). Buku Pedoman Praktikum dan Manual Alat Laboratorium Pendidikan Kimia. Jakarta: Departemen Pendidikan dan Kebudayaan.

Poerwadarminta, W.J.S. (1999). Kamus Besar Bahasa Indonesia. Jakarta : Balai Pustaka.

Purwadi, Sarosa dan Tobing, R.L., eds. Moedjiadi et al. (1981). Pengelolan Laboratorium IPA. Jakarta: Departemen Pendidikan dan Kebudayaan.

Sagala, Syaiful. (2008). Kemampuan Profesional Guru dan Tenaga Kependidikan. Bandung: Alfabeta.

Slameto. (2010). Belajar dan Faktor-Faktor Yang Memepengaruhinya. Bandung: Rineka Cipta.
Suminar, lin Tati. (2012). Pengaruh Penggunaan Media Pembelajaran dan Kompetensi Mengajar terhadap Hasil Belajar Siswa di SMAN 1 Cibungbulang, Kabupaten Bogor (Tesis). UNPAK Bogor: tidak diterbitkan.

Suprijono, Agus. (2013). Cooperative Learning. Yogyakarta: Pustaka Pelajar.

Suwahono. (2010). Keselamatan Kerja Laboratorium (Online). Tersedia: http://www.chem-istry.org/materi_kimia/kimiaaplikasi/manajemen-laboratoriumkimia/keselamatan-kerja-laboratorium/ (16 Oktober 2013).

Team teaching. (2011). Biologi Umum 1. Medan : FMIPA UNIMED.

Tirwani, Ani. (2011). Hubungan Pemanfaatan Laboraturium IPA dan Kemampuan Guru Mengelola Kelas dengan Prestasi Belajar Siswa (Tesis). UPI Bandung Jurusan Teknologi Pendidikan: tidak diterbitkan. 